This is an author produced version of a paper published in Forest ecology and management. This paper has been peer-reviewed and is proofcorrected, but does not include the journal pagination.

Citation for the published paper:

Fröberg, M., Hansson, K., Berggren Kleja, D., Alavi, G. (2011)

Dissolved organic carbon and nitrogen leaching from Scots pine, Norway spruce and silver birch stands in southern Sweden.

Forest ecology and management.

Volume: 262 Number: 9, pp 1742-1747

http://dx.doi.org/10.1016/j.foreco.2011.07.033

Access to the published version may require journal subscription.

Published with permission from: Elsevier

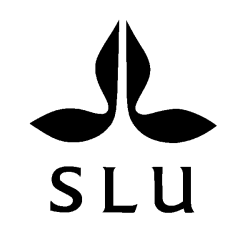

Epsilon Open Archive http://epsilon.slu.se 


\title{
Dissolved organic carbon and nitrogen leaching from Scots pine, Norway spruce and silver birch stands in southern Sweden
}

\author{
Mats Fröberg ${ }^{1 *}$, Karna Hansson ${ }^{2}$, Dan Berggren Kleja ${ }^{1}$, Ghasem Alavi $^{3}$
}

1. Swedish University of Agricultural Sciences, Department of Soil and Environment, P.O. Box 7001, SE-75007 Uppsala, Sweden.

2. Swedish University of Agricultural Sciences, Department of Ecology, P.O. Box 7044, SE-75007 Uppsala, Sweden.

3. SMHI (Swedish Meteorological and Hydrological Institute), Folkborgsvägen 1, 60176 Norrköping, Sweden.

* Corresponding author: telephone: +4618672233 , fax: +4618673470 , email: mats.froberg@slu.se

\begin{abstract}
The effects of three common tree species - Scots pine, Norway spruce and silver birch - on leaching of dissolved organic carbon and dissolved nitrogen were studied in an experimental forest with podzolised soils in southern Sweden. We analyzed soil water collected with lysimeters and modeled water fluxes to estimate dissolved $\mathrm{C}$ and $\mathrm{N}$ fluxes. Specific UV absorbance (SUVA) was analyzed to get information about the quality of dissolved organic matter leached from the different stands. Under the O horizon, DOC concentrations and fluxes in the birch stands were lower than in the spruce and pine stands; annual fluxes were $21 \mathrm{~g} \mathrm{~m}^{-2} \mathrm{y}^{-1}$ for birch and $38 \mathrm{~g} \mathrm{~m}^{-2} \mathrm{y}^{-1}$ and $37 \mathrm{~g} \mathrm{C} \mathrm{m}^{-2} \mathrm{y}^{-1}$ for spruce and pine, respectively. Under the $B$ horizon, annual fluxes for all tree species ranged between 3 and $5 \mathrm{~g} \mathrm{C} \mathrm{m}^{-2} \mathrm{y}^{-1}$, implying greater loss of DoC in the mineral soil in the coniferous stands than in the birch stands. We did not find any effect of tree species on the quality of the dissolved organic matter, as measured by SUVA, indicating that the chemical composition of the organic matter was similar in leachates from all three tree species. Substantial amounts of nitrogen was leached out of the soil profile at the bottom of the B horizon from the pine and birch stands, whereas the spruce stands seemed to retain most of the nitrogen in the soil. These differences in $\mathrm{N}$ leaching have implications for soil $\mathrm{N}$ budgets.
\end{abstract}

Keywords: Dissolved organic matter; tree species; dissolved organic carbon; forest soil; nitrogen; DOC quality

\section{Introduction}

The dominant tree species in a forest may have fundamental effects on soil properties, both biological, chemical and physical (e.g. Binkley and Giardina, 1998). Three different tree species constitute the majority ( $>90 \%$ ) of Swedish forests: Norway spruce (Picea abies) with $41 \%$, Scots Pine (Pinus sylvestris) with $39 \%$ and Birch (Betula pendula/B. pubescens) with $12 \%$ of standing volume (Anonymous 2010). A large majority of Scandinavian forests is managed and re-planting after harvest is common practice. The choice of tree species is an important forest management decision, which may also have implications for soil and ecosystem $\mathrm{C}$ and $\mathrm{N}$ budgets. In the project reported here, we have studied the effects of the three dominant Swedish tree species on dissolved C and N.

Dissolved organic carbon (DOC) may at first seem to be a negligible part of the $\mathrm{C}$ budget in forest soils. The DOC flux usually corresponds to a $\mathrm{C}$ flux of about two orders of magnitude or less compared to total gross ecosystem fluxes (Gielen et al. 2010; Kleja et al. 2008). It is however becoming increasingly obvious that such comparisons are not relevant and DOC should instead be compared to net ecosystem fluxes (Gielen et al. 2010; Siemens 2003). For example, Luyssaert et al. (2010) estimated that the average net European forest $\mathrm{C}$ sink is $75 \pm 20 \mathrm{~g} \mathrm{C} \mathrm{m}^{-2} \mathrm{y}^{-1}$, of which 22 $\mathrm{g} \mathrm{C} \mathrm{m}^{-2} \mathrm{y}^{-1}$ was accumulating in the soil. By comparison, the flux of $\mathrm{C}$ leaving the root zone as DOC from temperate forests is typically about 1-20 $\mathrm{g} \mathrm{m}^{-2}$ (summarized by Michalzik et al. 2001) and DOC leaching may thus play a significant role in the $\mathrm{C}$ budget of forest soils (Gielen et al. 2010). Furthermore, DOC also plays an important role in the internal C cycling in soils, as DOC is transported from the top soil to deeper parts of the soil, where it is retained by physico-chemical processes (Kalbitz et al. 2000). This leads to stabilization and thereby to a significant increased residence time of $\mathrm{C}$ in the soil (Kalbitz and Kaiser, 2008).

In this study, we present data on how birch, spruce and pine affect the quantity and quality of dissolved organic matter (DOM) leaching through the soil. Numerous studies of DOC transport in soils under different tree species have been made, but there are only few systematic investigations of the effects of the three dominant Scandinavian tree species in the literature. In previous studies of effects of birch, spruce and pine in Finland (Kiikkilä et al. 2006; Smolander and Kitunen, 2002; Suominen et al. 2003), higher concentrations of water extractable organic matter (WEOM) per gram of carbon were found under birch and spruce than under pine in the $\mathrm{O}$ horizon, but no differences were found between tree species for mineral soil samples. It can however be questioned how representative those studies are for field conditions, as water extracts were used instead of soil water collected with lysimeters. From other studies it has been concluded that WEOM data should be interpreted with caution as concentrations and quality may differ from actual dissolved carbon transported through the soil and collected with lysimeters (e.g. Fröberg et al. 2003). Here we present data based on collection of soil water with lysimeters. We are only aware of one previous study where lysimeters have been used to study DOC leaching from spruce, pine and birch. In that study, performed in northern Finland, there were higher DOC concentrations from pine stands than from birch stands, with DOC concentrations from spruce being intermediate (Lindroos et al 2011). Observations of differences in soil properties between birch and pine or spruce stands (e.g. Hansson et al. 2011) made us 
hypothesize that concentrations and fluxes of dissolved organic carbon would differ between stands dominated by spruce, pine and birch. In particular, we expected to find lower DOC fluxes under birch than under pine and spruce. As litter chemistry differs between the tree species, we also expected to find significant differences in DOC quality between birch and the coniferous tree species.

The effects of nitrogen leaching by different tree species have been more intensively studied than the effects on DOC. It is well established that the input of $\mathrm{N}$ via deposition is greater in highleaf-area conifers than low-leaf-area deciduous forests (Gundersen et al. 2009). It is not clear however, if this also results in larger $\mathrm{N}$ leaching from coniferous stands. The effects of tree species on $\mathrm{N}$ leached from stands dominated by difference tree species are often confounded, as different species tend to grow on soils with differing fertility (Kristensen et al. 2004). In this study, performed in an experimental forest, there are no such effects of initial differences in soil fertility. Hansson et al. (2011) reported, for the same plots used here, that soil $\mathrm{N}$ stocks were larger in the spruce and pine stands than in the birch stands. They suggested that difference in $\mathrm{N}$ leaching was one contributing reason for the differences in soil $\mathrm{N}$ stocks. We therefore also wanted to test the hypothesis that there are differences in dissolved $\mathrm{N}$ transport between the tree species.

\section{Methods}

\subsection{Site description}

The study area is located in the Tönnersjöheden Experimental Forest in south-west Sweden (56 $\left.-40-41^{\prime} \mathrm{N}, 13^{\circ} 03^{\circ}-06^{\prime} \mathrm{E}\right)$. Mean annual air temperature is $6.4^{\circ} \mathrm{C}$ and mean annual precipitation $1053 \mathrm{~mm}$. Mean annual N deposition during 2005-2008 was about $11 \mathrm{~kg} \mathrm{~N} \mathrm{ha}^{-1} \mathrm{y}^{-1}$ (Karlsson et al. 2010). The parent material is of glaciofluvial origin and the soils show signs of podzolisation, but are weakly developed and may be classified as either podzols, arenosols or regosols. The experimental design included stands of three different dominant tree species: Norway spruce (Picea abies (L) Karst.), Scots pine (Pinus sylvestris L.) and silver birch (Betula pendula Roth), replicated in a block design ( $n=3$, except for birch where $n=2$ ). The present stands were established in 1951-1963. Plot size ranged from 720 to $1296 \mathrm{~m}^{2}$. More details about the study sites can be found in Hansson et al. (2011).

\subsection{Soil solution sampling and analysis}

In each plot, 3 zero-tension lysimeters, (30 cm squares, made of plexiglass and a polyethylene net) were installed under the $\mathrm{O}$ horizon. Under the A horizon, at 10-16 cm depth from the soil surface, 2 Prenart Soil Disc lysimeters (Prenart Equipment Aps, Frederiksberg, Denmark) were installed per plot. Under the B horizon, at 42-50 cm depth from the soil surface, 2 Prenart Super Quartz lysimeters (Prenart Equipment Aps, Frederiksberg, Denmark) were installed. Water was collected monthly and pooled per plot and horizon prior to DOC and total dissolved nitrogen (DN) analysis. O horizon samples were filtered before analysis $(0.2$ or $0.45 \mu \mathrm{m})$. For A and B horizon samples, no further filtration after collection with Prenart lysimeters was made, as they did not contain particulate organic matter. Analyses of DOC and DN were made with a Shimadzu TOC-VCPH and Shimadzu TNM-1, respecttively. In addition specific UV absorbance was measured at $260 \mathrm{~nm}$ (Perkin Elmer Lambda 11) and $\mathrm{pH}$ was measured on all pooled samples. Specific ultraviolet absorbance at $260 \mathrm{~nm}\left(\mathrm{SUVA}_{260}\right)$ was calculated as absorbance divided by DOC concentration.

\subsection{Water flux modeling}

The water fluxes were simulated using the CoupModel (Jansson and Karlberg, 2004). The driving climate variables were daily sum of precipitation, daily averages of air temperature, air humidity, wind speed and solar radiation. These variables, with the exception for wind speed, were provided from the nearby Simlångsdalen. Wind speed was taken from the SMHI meteorological station at Ullared. Further, precipitation was adjusted by $+7 \%$ for the aerodynamic error in precipitation measurements.

Soil hydraulic parameters were estimated for each plot by using the measured soil texture and pedofunctions as proposed by Rawl and Brankensiek (1989). The leaf area indices (including understory) were measured in each plot during summer 2010. The root densities were estimated from the measured root biomass. The other stand parameters were taken from Alavi (2002), Gärdenäs \& J ansson (1995) and Richardson \& Berlyn (2002) for spruce, pine and birch respectively.

\subsection{Statistical analysis}

Statistical analyses of differences in soil solution concentrations were made using process mixed in SAS 9.2. The 'Repeated' statement was used to account for the temporal dependency of successive measurements close in time. DOC and DN concentrations were log-transformed before statistical analysis. Back-transformed mean was estimated as $\exp \left(\right.$ mean $\left.+0.5 \mathrm{~s}^{2}\right)$, with mean and variance, $\left(\mathrm{s}^{2}\right)$, on the log-transformed scale. Effects of tree species, block, sampling occasion and the interaction between sampling occasion and treatment were included in the analyses.

To be able to estimate the total transport of $\mathrm{C}$ and $\mathrm{N}$ during the observed time period, together with a confidence interval, we modeled concentrations for all series with the same tree species by a smooth curve using a smoothing spline (Hastie et al. 2001). The smoothness of the curve was determined by generalized cross validation (GCV). Residuals were computed as the difference between observed concentrations and the smoothed curve and a large number of new series of concentrations were created by randomly resampling the residuals and adding them to the original smoothed curve. For each of these new series the concentrations were multiplied to the observed water discharge and summed over all observations during the time period of the study. From these estimations of total transport of $\mathrm{C}$ or $\mathrm{N}$, we collect the 2.5th and 97.5th percentile to define a $95 \%$ confidence interval for the total transport. This is also called the bootstrapped percentile interval (Efron and Tibshirani, 1993). Fluxes are reported as annual means. 

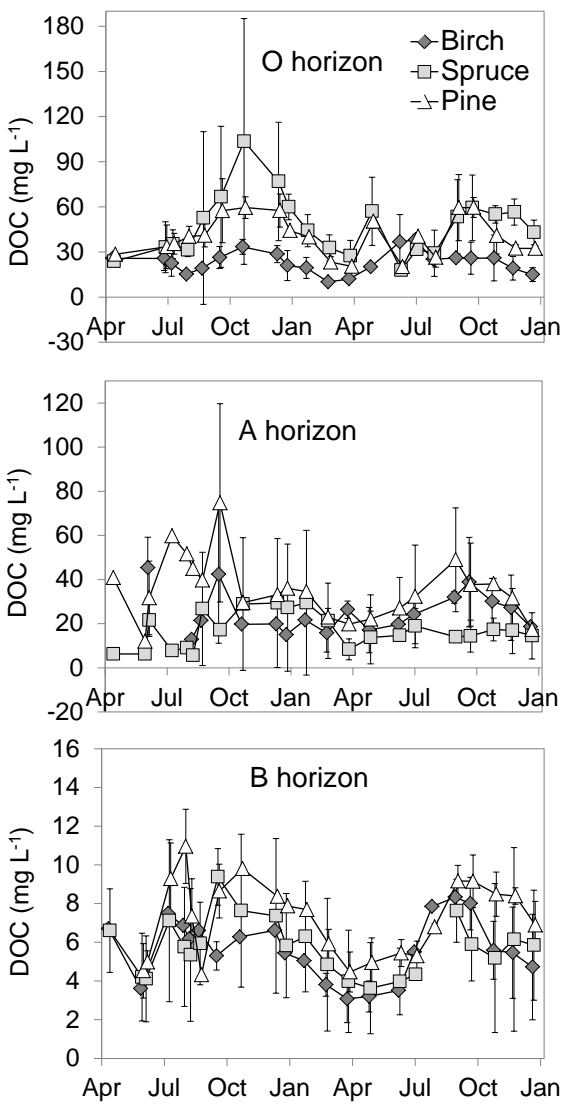

Figure 1. DOC concentrations in soil water collected with lysimeters under the O, A and B horizon. Error bars represent standard deviations ( $\mathrm{n}=2$ or 3 ).

\section{Results}

\subsection{DOC}

The temporal variations in $\mathrm{DOC}$ concentrations in the $\mathrm{O}, \mathrm{A}$ and $\mathrm{B}$ horizons are illustrated in Figure 1. DOC concentrations under the O horizon in the birch stands were significantly lower than in the spruce or pine stands ( $\mathrm{p}=0.001$ and 0.004 , respectively) (Table 1 ). Average DOC concentration under the $\mathrm{O}$ horizon in the birch stands was $25 \mathrm{mg} \mathrm{L}^{-1}$ and in the spruce and pine stands 43 and 39 $\mathrm{mg} \mathrm{L}^{-1}$ (Table 1). For all horizons, water fluxes were largest under birch and smallest under spruce and therefore the relative difference between tree species was smaller for fluxes than for concentrations in the $\mathrm{O}$ horizon. Annual fluxes were $38 \mathrm{~g} \mathrm{~m}^{-2} \mathrm{y}^{-1}$ and $37 \mathrm{~g} \mathrm{~m}^{-2} \mathrm{y}^{-1}$ for spruce and pine respectively and $21 \mathrm{~g} \mathrm{~m}^{-2} \mathrm{y}^{-1}$ for birch (Figure 2).

Under the A horizon, there were no statistically significant differences between treatments for DOC concentrations (Figure 1). Mean DOC concentration in the pine stands was $34 \mathrm{mg} \mathrm{L}^{-1}$ and in the birch and spruce stands 26 and $21 \mathrm{mg} \mathrm{L}^{-1}$, respectively (Table 1). DOC fluxes were 27, 23 and $13 \mathrm{~g} \mathrm{~m}^{-2} \mathrm{y}^{-1}$ for pine, birch and spruce (Figure 2). The difference in DOC fluxes under the A horizon between spruce on one hand and pine or birch on the other was statistically significant $(\mathrm{p}<0.05)$. The smallest water flux occurred in the spruce stands, which explains the larger relative difference between fluxes than between concentrations. DOC fluxes and concentrations thus decreased between the $\mathrm{O}$ horizon and the A horizon in the coniferous stands - especially for spruce but not in the birch stands.

In the B horizon the DOC concentrations were substantially lower than in the upper soil horizons for all tree species (Figure 1). Average DOC concentrations were 6, 5 and $8 \mathrm{mg} \mathrm{L}^{-1}$ for birch, spruce and pine, respectively (Table 1 ). The corresponding fluxes were 4,3 and $5 \mathrm{~g} \mathrm{~m}^{-2} \mathrm{y}^{-1}$ (Figure 2). The difference between spruce and pine was statistically significant.
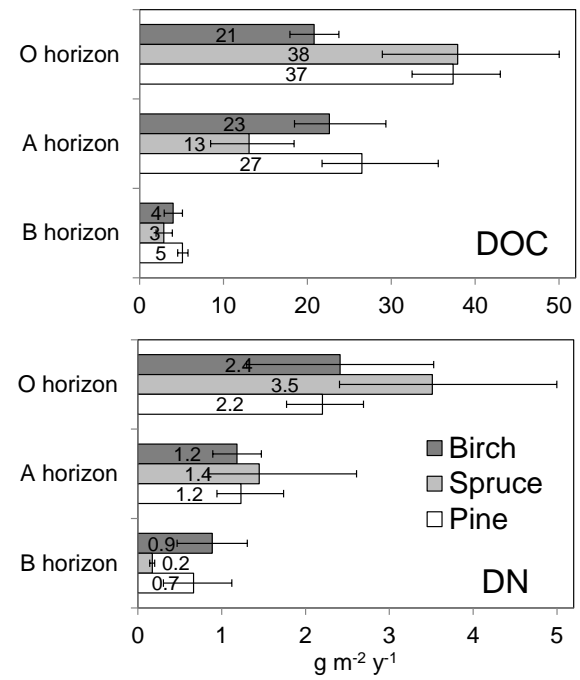

Figure 2. Fluxes of dissolved organic carbon (DOC) and dissolved nitrogen (DN). Error bars represent the 95\% confidence interval (95\% bootstrapped percentile interval)

\subsection{DN}

$\mathrm{DN}$ concentrations in leachates under the $\mathrm{O}$ horizon were highest in the spruce stands, with on average $4,7 \mathrm{mg} \mathrm{L}^{-1}$, whereas the DN concentrations in the birch and pine stands were 2.8 and $2.5 \mathrm{mg} \mathrm{L}^{-1}$ respectively (Table 1). This corresponds to fluxes of $3.5 \mathrm{~g} \mathrm{~m}^{-2} \mathrm{y}^{-1}$ from the spruce stands and 2.4 and $2.2 \mathrm{~g} \mathrm{~m}^{-2} \mathrm{y}^{-1}$ from birch and pine (Figure 2). The higher concentrations - but not the fluxes - in the spruce stands, under the $\mathrm{O}$ horizon, were statistically signifycant at $\mathrm{p}<0.05$ level. Under the A horizon, there were no major differences between treatments. DN concentrations in this horizon ranged between 1.5 and $1.8 \mathrm{mg} \mathrm{L}^{-1}$ (Table 1) and fluxes ranged between 1.2 and $1.4 \mathrm{~g} \mathrm{~m}^{-2} \mathrm{y}^{-1}$ (Figure 2). In the B horizon the DN concentration and flux in the spruce stands was significantly lower than for the other two species. The DN concentrations under the $\mathrm{B}$ horizon were 1.9, 0.3 and $0.9 \mathrm{mg} \mathrm{L}-1$ for birch, spruce and pine respectively (Table 1). Fluxes were $0.9 \mathrm{~g} \mathrm{~m}^{-2} \mathrm{y}^{1}$ in the birch stands, $0.2 \mathrm{~g} \mathrm{~m}^{-2} \mathrm{y}^{1}$ in spruce stands and $0.7 \mathrm{~g} \mathrm{~m}^{-2} \mathrm{y}^{-1}$ in pine stands (Figure 2).

\section{3. $\mathrm{pH}$}

The $\mathrm{pH}$ was significantly higher in the birch stands than in the coniferous stands under the $\mathrm{O}$ and $\mathrm{A}$ horizons (Table 1). Mean $\mathrm{pH}$ in the birch stands were 5.0 and 4.7 in the $\mathrm{O}$ and $\mathrm{A}$ horizons, respectively and in the spruce and pine stands 4.3-4.4 in both horizons. The same trend appeared also in the B horizon with lower $\mathrm{pH}$ under spruce (4.6) than under birch (4.8) and pine (4.7) (Table 1). 
Table 1. Concentrations of DOC and DN (mg L-1), specific UV absorption (SUVA) at $260 \mathrm{~nm}$ (L mg-1 m-1) and pH.

\begin{tabular}{ccccc}
\hline & Horizon & Birch & Spruce & Pine \\
\hline \multirow{3}{*}{ DOC } & $\mathrm{O}$ & $25(20-31) \mathrm{a}$ & $43(36-51) \mathrm{b}$ & $39(33-46) \mathrm{b}$ \\
& $\mathrm{A}$ & $26(17-42) \mathrm{a}$ & $21(14-29) \mathrm{a}$ & $34(24-49) \mathrm{a}$ \\
& $\mathrm{B}$ & $6(4-8) \mathrm{ab}$ & $5(4-6) \mathrm{a}$ & $8(6-10) \mathrm{b}$ \\
\hline \multirow{3}{*}{$\mathrm{DN}$} & $\mathrm{O}$ & $2.8(2.3-3.5) \mathrm{a}$ & $4.7(3.9-5.6) \mathrm{b}$ & $2.5(2.1-3.0) \mathrm{a}$ \\
& $\mathrm{A}$ & $1.8(1.2-2.5) \mathrm{a}$ & $1.6(1.2-2.2) \mathrm{a}$ & $1.5(1.1-2.1) \mathrm{a}$ \\
& $\mathrm{B}$ & $1.9(1.1-3.0) \mathrm{a}$ & $0.3(0.2-0.5) \mathrm{b}$ & $0.9(0.6-1.3) \mathrm{a}$ \\
\hline \multirow{3}{*}{ SUVA } & $\mathrm{O}$ & $4.6(4.2-5.1) \mathrm{a}$ & $4.5(4.2-4.9) \mathrm{a}$ & $4.5(4.1-4.9) \mathrm{a}$ \\
& $\mathrm{A}$ & $3.9(3.5-4.4) \mathrm{a}$ & $3.4(3.0-3.8) \mathrm{a}$ & $3.8(3.4-4.1) \mathrm{a}$ \\
& $\mathrm{B}$ & $2.2(1.7-2.6) \mathrm{a}$ & $2.1(1.7-2.4) \mathrm{a}$ & $2.6(2.3-3.0) \mathrm{a}$ \\
\hline & $\mathrm{O}$ & $5.0(4.9-5.2) \mathrm{a}$ & $4.4(4.2-4.5) \mathrm{b}$ & $4.3(4.1-4.5) \mathrm{b}$ \\
$\mathrm{pH}$ & $\mathrm{A}$ & $4.7(4.5-4.9) \mathrm{a}$ & $4.4(4.2-4.5) \mathrm{b}$ & $4.3(4.2-4.5) \mathrm{b}$ \\
& $\mathrm{B}$ & $4.8(4-7-4.9) \mathrm{a}$ & $4.6(4.5-4.7) \mathrm{b}$ & $4.7(4.6-4.8) \mathrm{a}$ \\
\hline
\end{tabular}

\subsection{SUVA}

SUVA $_{20}$ decreased significantly with DOC concentration and soil depth (Figure 3). Low DOC concentrations were associated with low UV absorbance, both compared across soil horizon and within each horizon. There were no major differences in specific UV absorbance between tree species at any depth (Table 1).

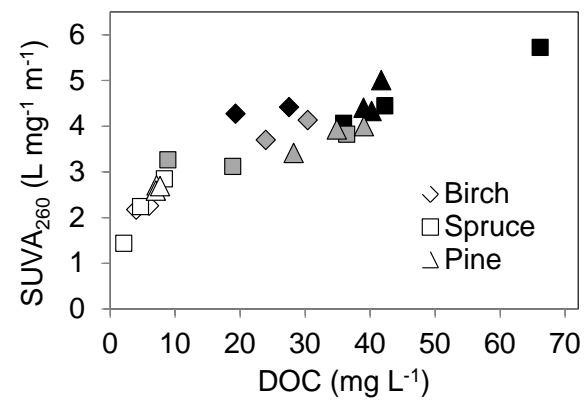

Figure 3. Specific UV absorbance (SUVA) as a function of DOC concentration. Filled black symbols represent the $\mathrm{O}$ horizon, grey symbols the A horizon and open symbols the B horizon.

\section{Discussion}

The data presented here demonstrate that there were differences in DOC concentrations (Table 1) and fluxes (Figure 2) under the $\mathrm{O}$ horizon between birch stands on one hand and pine and spruce stands on the other. This difference was in line with expectations and the lower DOC concentrations and fluxes under the O horizon in the birch stands are likely related to the thinner $\mathrm{O}$ horizons in these stands. A previous study in the same stands showed that soil chemistry differs significantly between tree species, as there were higher $\mathrm{pH}$ and base saturation in the birch stands (Hansson et al. 2011). In addition that study showed that the O horizons in the birch stands were thinner than in the coniferous stands and mixed with mineral soil. The effects of tree species on several chemical, physical and biological properties of the soil is documented previously (e.g. Augosto et al. 2002; Binkley and Giardina 1998). In other experiments with different tree species it has been shown that spruce forests in Scandinavia have low $\mathrm{pH}$ and large $\mathrm{C}$ stocks in the O horizon (Oostra et al 2006; Vesterdal et al. 2008). The thinner $\mathrm{O}$ horizon in birch stands, both at our study site and in general, is likely related to differences in litter composition between birch leaves and pine and spruce needles, resulting in more bioturbation in the birch stands. This effect has been shown earlier by Saetre (1998), who reported that mixing birch in spruce stands substantially increase earthworm activity.

The results may be compared to results from other studies. In a review of DOC in temperate forests, Michalzik et al. 2001 did not find any difference in DOC and DON concentrations and fluxes in forest floor leachates when comparing coniferous and hardwood sites. In an experimental forest in Massachusetts, DOC was lower and DON and DIN fluxes higher from the $\mathrm{O}$ horizon under pine than in the deciduous stands, but there were only small differences in DOC under the rooting zone (Currie et al. 1996; McDowell et al. 2004). Other direct comparisons of tree species effects on DOC are scarce, especially when interested in spruce, pine and birch, more specifically. There are data from Finland comparing water extracts from the three species, indicating that there is less water soluble carbon leached from pine stands than from spruce and birch (Smolander and Kitunen, 2002; Suominen et al., 2003). In a recent study, Lindroos et al. (2011) measured highest DOC concentration from pine stands under the $\mathrm{O}$ horizon; significantly higher than under birch, with spruce having intermediate concentrations.

DOC fluxes are perhaps more interesting to compare than concentrations. Water fluxes in the spruce stands were substantially lower than in the birch and pine stands. Estimated annual water fluxes under the O horizon were 940, 710 and $890 \mathrm{~mm}$ for birch, spruce and pine, respectively. The relative difference increased with depth and under the B horizon estimated fluxes were $810 \mathrm{~mm}$ for birch, $550 \mathrm{~mm}$ for spruce and $690 \mathrm{~mm}$ for pine. This difference in water flux is related to differences in leaf area, which has a large influence on transpiration and interception loss and was greatest for spruce. Low water flux under spruce stands is also in accordance with other Scandinavian studies (Christiansen et al. 2006, 2010). The relative difference in DOC flux from the O horizon between tree species was thus lower than the relative difference in concentrations from the same horizon, but there were still larger fluxes from the coniferous stands compared to the birch stands. 

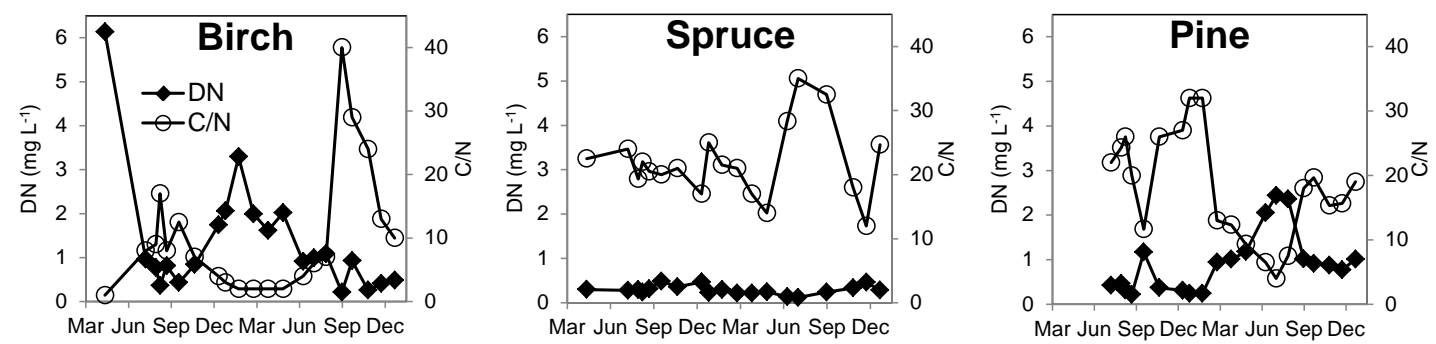

Figure 4. Total dissolved nitrogen $(\mathrm{DN})$ and Dissolved organic carbon/ DN ratios $(\mathrm{C} / \mathrm{N})$ under the B horizon for birch, spruce and pine. High DN concentrations coincide with low $\mathrm{C} / \mathrm{N}$ ratios, strongly suggesting a large proportion of inorganic $\mathrm{N}$.

Contrary to our expectations, there was no difference in DOM quality as revealed by UV absorbance between different tree species in any of the horizons (Figure 3), despite clear effects on soil chemistry between the tree species (Hansson et al. 2011). DOC leached from litter from different tree species has previously been shown to differ in SUVA (Hongve, 2000) and in water extracts from $\mathrm{O}$ horizons, birch has been found to have higher concentration of phenolic compounds than spruce (Smolander et al. 2005). We had therefore hypothesized that there would be differences in DOC quality between the tree species and especially between birch on one hand and the coniferous trees on the other. This was however not the case, although this should not have been totally unexpected; other studies on water extracts have shown that there are no or only minor differences in size and chemical fractions in dissolved organic matter from birch, pine and spruce stands (Kiikkilä et al. 2006, 2011; Smolander et al. 2005; Smolander and Kitunen 2002). One explanation for the small differences in DOC composition between tree species quality could be that DOC largely originates in decomposed organic matter in the lower parts of the O horizon (Fröberg et al. 2003, 2007b; Hagedorn et al. 2004), where differences between birch leaves and coniferous needles are smaller than in fresh litter (Kiikkilä et al. 2011).

Whereas there were no effects of tree species on DOC quality, there was a positive relationship between DOC concentration and SUVA and furthermore also a trend with decreasing SUVA with depth in the soil profile. The same trend with SUVA changing with depth has been reported previously by Hagedorn et al. (2000), Don et al. (2008) and Sanderman et al. (2008, 2009) who explained this by additions of DOC with low SUVA at depth. An alternative explanation would be preferential adsorption of hydrophobic organic matter, but this is likely not the case as isotope data have shown that DOC from fresh litter is retained in the upper part of the soil and replaced by old carbon from the mineral soil (Fröberg et al. 2007a, Sanderman et al. 2008, Tate et al. 2011). This strong physico-chemical control of DOC by minerals also explains why the difference in DOC concentrations and fluxes under the $\mathrm{O}$ horizon between tree species was not found in the mineral soil in our study.

Increasing $\mathrm{pH}$ as an explanation of rising DOC concentrations in streams and lakes in large areas in Europe and North America has got much attention during the last decade (e.g. Monteith et al. 2007; Roulet and Moore, 2006). According to the hypothesis, decreasing acid inputs have resulted in increasing $\mathrm{pH}$ and as a consequence increasing DOC concentrations in surface waters (Evans et al. 2006). The effect is thus opposite to what we found here, i.e. lower DOC concentration and fluxes from the $\mathrm{O}$ horizon of the birch stands where $\mathrm{pH}$ was significantly higher than in the coniferous stands. Although it is well established that organic matter solubility increases with increasing $\mathrm{pH}$, this effect was not manifested in our study. As discussed above, we instead suggest that the differences in soil chemistry under different tree species, in particular the higher $\mathrm{pH}$ under birch, was one reason for the thinner $\mathrm{O}$ horizon in the birch stands under this horizon. This in turn is likely to result in lower DOC concentrations (Fröberg et al. 2005). The lower DOM flux from the O horizon under birch than in coniferous stands, in combination with similar DOM flux in the mineral soil regardless of dominant tree species, imply that there is a lower transport of DOM from the $\mathrm{O}$ horizon to the mineral soil in the birch stands. This could have implications for long-term $\mathrm{C}$ budgets in the mineral soil. As reported previously (Hansson et al 2011) there was a significant difference in O horizon SOC stocks between the tree species, with largest $\mathrm{C}$ stock in the spruce stands and lowest $\mathrm{C}$ stocks in the birch stands. The differences in the mineral soil were however not as obvious. As the $\mathrm{C}$ stocks in the mineral soil change only slowly, an effect on the $C$ stocks was not to expect. However, if extrapolated into the future a difference in DOC influx to the mineral soil could have implications also for mineral soil C stocks. Biological mixing is however probably of greater relative importance in the birch stand than in the coniferous stands and it thus seems like in pine and spruce forests, DOC is a more important pathway for translocation of carbon from the upper to the lower parts of the soil profile when compared to birch forests, whereas the opposite may be true for physical mixing as a means of transporting soil carbon from the surface to deeper horizons.

The DN data show that a considerable amount of $\mathrm{N}$ was leached through the soil. Furthermore, low C:N ratios in solution coincide with high $\mathrm{DN}$, which shows that a significant fraction of the $\mathrm{N}$ was transported in inorganic form at all sampled depths, i.e. all the way down below the B horizon (Figure 4). This was also obvious from a few measurements (four sampling occasions) of ammonium and nitrate (data not presented). Effects of tree species on $\mathrm{N}$ leaching has been studied previously and one typical observation is greater influx of $\mathrm{N}$ via deposition in coniferous species compared to deciduous, but no major differences between coniferous and deciduous stands in N leaching from the soil (Christiansen et al 2010; Gundersen et al. 2009). This is in accordance with the data presented here. The nitrogen flux under the O horizon was highest under spruce, but more $\mathrm{N}$ was leaving the rooting 
zone from the birch and pine stands than from the spruce stands (Figure 2). Accordingly, more $\mathrm{N}$ is circulating in the spruce stands than in the pine or birch stands. The spruce stands seem to have the ability to retain $\mathrm{N}$ within the system, whereas $\mathrm{N}$ is apparently lost from the pine and birch stands (Figure 4). In a previous study, it was demonstrated that the total soil organic $\mathrm{N}$ pool at our study site was greatest under in the spruce stands (Hansson et al. 2011). Approximately $100 \mathrm{~g}$ more $\mathrm{N}$ per square meter had accumulated in soil organic matter in the spruce stands than in the birch stands, already approximately 50 years after the stands were established. This difference in $\mathrm{N}$ stock corresponds to $2 \mathrm{~g} \mathrm{~N} \mathrm{~m}^{-2}$ for every year since the establishment of the experiment. We do not have the ambition, in this study, to make a complete $\mathrm{N}$ budget for the different stands. However, the difference in soil N stocks presented by Hansson et al. (2011), in combination with the data presented here, suggest a strong link between tree species, soil organic matter accumulation and $\mathrm{N}$ leaching. The flux of dissolved $\mathrm{N}$ in leachates from the birch and pine stands corresponds to about half of the annual $\mathrm{N}$ deposition or more, whereas the amount of $\mathrm{N}$ leached from the spruce stands was minor, in accordance with the large differences in soil $\mathrm{N}$ pools at this site, previously presented by Hansson et al. (2011).

\section{Acknowledgements}

This study was originally initiated by Professor Hooshang Majdi, deceased 2007. The research was supported by the Swedish Research Council for Environment, Agricultural Sciences and Spatial Planning. Thanks to the staff at Tönnersjöheden Experimental Forest for help with collecting data, Bo Bergkvist for help with lysimeters installations, Tommy Olsson for chemical analyses and Claudia von Brömssen for help with statistical analyses.

\section{References}

Alavi G, 2002. The impact of soil moisture on stem growth of spruce forest during a 22year period. For. Ecol. Manag. 166, 17-33.

Anonymous, 2010. Skogsdata 2010. Aktuella uppgifter om de svenska skogarna från riksskogstaxeringen. Department of Forest Resource Management, Swedish University of Aricultural Sciences, Umeå. (In Swedish).

Augosto L, Ranger J, Binkley D, Rothe A, 2002. Impact of several common tree species of European temperate forests on soil fertility. Ann. For. Sci. 59, 233-253.

Binkley D, Giardina C, 1998. Why do trees species affect soils? The warp and woof of treesoil interactions. Biogeochem. 42, 89-106.

Christiansen JR, Elberling B, J ansson P-E, 2006. Modelling water balance and nitrate leaching in temperate Norway spruce and beech forests located on the same soil type with the CoupModel. For. Ecol. Manag. 237, 545-556.

Christiansen JR, Vesterdal L, Callesen I, Elberling B, Schmidt IK, Gundersen P, 2010. Role of six European tree species and land-use legacy for nitrogen and water budgets in forests. Global Change Biol. 16, 2224-2240.

Currie WS, Aber JD, McDowell WH, Boone RD, Magill AH, 1996. Vertical transport of dissolved organic $\mathrm{C}$ and $\mathrm{N}$ under long-term $\mathrm{N}$ amendments in pine and hardwood forests. Biogeochem. 35, 471-505

Don A, Schulze ED, 2008. Controls on fluxes and export of dissolved organic carbon in grasslands with contrasting soil types. Biogeochem. 91, 117-131.

Efron B, Tibshirani R, 1993. An introduction to the Bootstrap, Chapman \& Hall.

Evans CD, Chapman PJ, Clark JM, Monteith DT, Cresser MS, 2006. Alternative explanations for rising dissolved organic carbon export from organic soils. Global Change Biol. 12, 2044-2053.

Fröberg M, Berggren D, Bergkvist B, Bryant C, Knicker H, 2003. Contributions of Oi, Oe and Oa horizons to dissolved organic matter in forest floor leachates. Geoderma 113, 311-322.

Fröberg M, Kleja DB, Bergkvist B, Tipping E, Mulder J , 2005. Dissolved organic carbon leaching from a coniferous forest floor - a field manipulation experiment. Biogeochem. 75, 271-287.

Fröberg M, Jardine PM, Hanson PJ, Swanston CW, Todd DE, Tarver JR, Garten CT, 2007a. Low dissolved organic carbon input from fresh litter to deep mineral soils. Soil Sci. Soc. Am. J. 71, 347-354.

Fröberg M, Kleja DB, Hagedorn F, 2007b. The contribution of fresh litter to dissolved organic carbon leached from a coniferous forest floor. Eur. J. Soil Sci. 58, 108-114.

Gärdenäs AI, Jansson P-E, 1995. Simulated water balance of Scots pine stands in Sweden for different climate change scenarios. J. Hydrol. 166, 107-125.
Gielen B, Neirynck J, Luyssaert S, Janssens IA, 2010. The importance of dissolved onganic carbon fluxes for the carbon balance of a temperate Scots pine forest. Agric. For. Meteorol. 151, 270-278

Gundersen P, Sevel L, Christiansen JR, Vesterdal L, Hansen K, Bastrup-Birk A, 2009. Do indicators of nitrogen retention and leaching differ between coniferous and broadleaved forests in Denmark? For. Ecol. Manag. 258, 1137-1146.

Hagedorn F, Saurer M, Blaser P, 2004. A ${ }^{13} \mathrm{C}$ tracer study to identify the origin of dissolved organic carbon in forested mineral soils. Eur. J . Soil Sci. 55, 91-100.

Hagedorn F, Schleppi P, Waldner P, Fluhler H, 2000. Export of dissolved organic carbon and nitrogen from Gleysol dominated catchments - the significance of water flow paths. Biogeochem. 50, 137-161.

Hansson K, Olsson BA, Olsson M, Johansson U, Kleja DB, 2011. Differences in soil properties in adjacent stands of Scots pine, Norway spruce and silver birch in SW Sweden. For. Ecol. Manag. 262, 522-530.

Hastie T, Tibshirani R, Friedman J, 2001. The elements of statistical learning, Data mining, Inference and prediction, Springer.

Hongve D, van Hees PAW, Lundström US, 2000. Dissolved components in precipitation water percolated through forest litter. Eur.J. Soil Sci. 51, 667-677.

Jansson P-E, Karlberg L, 2004. Coupled heat and mass transfer model for soil-plantatmosphere systems. Royal Institute of Technology, Dept. of Civil and Environmenta Engineering, Stockholm, Sweden (ftp:// www.lwr.kth.se/CoupModel/CoupModel.pdf)

Kalbitz K, Kaiser K, 2008. Contribution of dissolved organic matter to carbon storage in forest mineral soils. J. Plant Nutr. Soil Sci. 171, 52-60.

Kalbitz K, Solinger S, Park J-H, Michalzik B, Matzner E, 2000. Controls on the dynamics of dissolved organic matter in soils: a review. Soil Sci. 165, 277-304.

Karlsson GP, Akselsson C, Hellsten S, Karlsson PE, Malm G, 2010. Övervakning av luftföroreningar i Hallands län - mätningar och modellering. IVL rapport B1912.

Kiikkilä O, Kitunen V, Smolander A, 2006. Dissolved soil organic matter from surface organic horizons under birch and conifers: Degradation in relation to chemical characteristics. Soil Biol. Biochem. 38, 737-746.

Kiikkilä O, Kitunen V, Smolander A, 2011. Properties of dissolved organic matter derived from silver birch and Norway spruce stands: Degradability combined with chemical characteristics. Soil Biol. Biochem. 43, 421-430.

Kleja DB, Svensson M, Majdi H, Jansson P-E, Langvall O, Bergkvist B, Johansson M-B, Weslien P, Truus L, Lindroth A, Ågren GI, 2008. Pools and fluxes of carbon in three Norway spruce ecosystems along a climatic gradient in Sweden. Biogeochem. 89, 7-25.

Kristensen HL, Gundersen P, Callesen I, Reinds GJ, 2004. Throughfall nitrogen deposition has different impacts on soil solution nitrate concentration in European coniferous and deciduous forests. Ecosystems 7, 180-192.

Lindroos A-J, Derome K, Derome K, Smolander A, 2011. The effect of Scots pine, Norway spruce and silver birch on the chemical composition of stand throughfall and upper soil percolation water in northern Finland. Boreal Environ. Res. 16, 240-250.

Luyssaert S, Ciais P, Piao SL, Schulze ED, J ung M, Zaehle S, Schelhaas MJ, Reichstein M, Churkina G, Papale D, Abril G, Beer C, Grace J, Loustau D, Matteucci G, Magnani F, Nabuurs GJ, Verbeeck H, Sulkava M, van der Werf GR, Janssens IA, 2010. The European carbon balance. Part 3: forests Global Change Biol. 16, 1429-1450.

McDowell WH, Magill AH, Aitkenhead-Peterson A, Aber JD, Merriam JL, Kaushal SS, 2004. Effects of chronic nitrogen amendment on dissolved organic matter and inorganic nitrogen in soil solution. For. Ecol. Manag. 196, 29-41.

Michalzik B, Kalbitz K, ParkJ-H, Solinger S, Matzner E, 2001. Fluxes and concentrations of dissolved organic carbon and nitrogen - a synthesis for temperate forests. Biogeochem. 52, 173-205.

Monteith DT, Stoddard JL, Evans CD, de Wit HA, Forsius M, Høgåsen T, Wilander A Skjelkvåle BL, Jeffries DS, Vuorenmaa J, Keller B, Kopácek J, Vesely J, 2007. Dissolved organic carbon trends resulting from changes in atmospheric deposition chemistry. Nature $450,537-540$

Oostra S, Majdi H, Olsson M, 2006. Impact of tree species on soil carbon stocks and soil acidity in southern Sweden. Scand. J. For. Res. 21, 364-371.

Rawl WJ, Brankensiek DL, 1989. Estimation of soil water retention and hydraulic properties. In: HG Morel-Seytoux (Ed) Unsaturated flow in hydrological modelling theory and practice, Kluwer Academic Publishers, pp. 275-300.

Richardson AD, Berlyn GP, 2002. Spectral reflectance and photosynthetic properties of Betula Papyrifera (Betulaceae) leaves along an elevational gradient on Mt. Mansfield, Vermont, USA. American J. Bot. 89, 88-94.

Roulet N, Moore TR, 2006. Browning the waters. Nature 444, 283-284.

Saetre P, 1998. Decomposition, microbial community structure, and earthworm effects along a birch-spruce soil gradient. Ecology 79, 834-846.

Sanderman J, Baldock J A, Amundson R, 2008. Dissolved organic carbon chemistry and dynamics in contrasting forest and grassland soils. Biogeochem. 89, 181-198.

Sanderman J, Lohse KA, Baldock JA, Amundson R, 2009. Linking soils and streams: Sources and chemistry of dissolved organic matter in a small coastal watershed Water Resour. Res. 45, W03418.

Siemens J , 2003. The European Carbon Budget: A Gap. Science 302 (5651), 1681.

Smolander A, Kitunen V, 2002. Soil microbial activities and characteristics of dissolved organic $\mathrm{C}$ and $\mathrm{N}$ in relation to tree species Soil Biol. Biochem. 34, 651-660.

Smolander A, Loponen J, Suominen K, Kitunen V, 2005. Organic matter characteristic and $\mathrm{C}$ and $\mathrm{N}$ transformations in the humus layer under two tree species, Betula pendula and Picea abies. Soil Biol. Biochem. 37, 1309-1318.

Suominen K, Kitunen V, Smolander A, 2003. Characteristics of dissolved organic matter and phenolic compounds in forest soils under silver birch (Betula pendula), Norway spruce (Picea abies) and Scots pine (Pinus sylvestris). Eur. J. Soil Sci. 54, 287-293.

Tate KR, Lambie SM, Ross DJ, Dando J, 2011. Carbon transfer from ${ }^{14} \mathrm{C}$-labelled needles to mineral soil, and ${ }^{14} \mathrm{C}-\mathrm{CO} 2$ production, in a young Pinus radiata Don stand. Eur. J. Soil Sci. 62, 127-133.

Vesterdal L, Schmidt IK, Callesen I, Nilsson LO, Gundersen P, 2008. Carbon and nitrogen in forest floor and mineral soil under six common European tree species. For. Ecol. Manag. 255, 35-48. 